\title{
Interactive comment on "Validation of aerosol backscatter profiles from Raman lidar and ceilometer using balloon-borne measurements" by Simone Brunamonti et al.
}

Simone Brunamonti et al.

brunamontisimone@gmail.com

Received and published: 15 October 2020

The comment was uploaded in the form of a supplement:

https://acp.copernicus.org/preprints/acp-2020-294/acp-2020-294-AC1-supplement.pdf

Interactive comment on Atmos. Chem. Phys. Discuss., https://doi.org/10.5194/acp-2020-294, 2020. 